University of Nebraska - Lincoln

DigitalCommons@University of Nebraska - Lincoln

Publications from USDA-ARS / UNL Faculty

U.S. Department of Agriculture: Agricultural

Research Service, Lincoln, Nebraska

2000

Spring Wheat Response to Tillage System and Nitrogen

Fertilization within a Crop-Fallow System

Ardell D. Halvorson

USDA-ARS, adhalvor@lamar.colostate.edu

Alfred L. Black

USDA-ARS

Joseph M. Krupinsky

USDA-ARS

Steven D. Merrill

USDA-ARS

B. J. Wienhold

University of Nebraska-Lincoln, Brian.Wienhold@ars.usda.gov

See next page for additional authors

Follow this and additional works at: https://digitalcommons.unl.edu/usdaarsfacpub

Halvorson, Ardell D.; Black, Alfred L.; Krupinsky, Joseph M.; Merrill, Steven D.; Wienhold, B. J.; and Tanaka, Donald L., "Spring Wheat Response to Tillage System and Nitrogen Fertilization within a Crop-Fallow System" (2000). Publications from USDA-ARS / UNL Faculty. 1181.

https://digitalcommons.unl.edu/usdaarsfacpub/1181

This Article is brought to you for free and open access by the U.S. Department of Agriculture: Agricultural Research Service, Lincoln, Nebraska at DigitalCommons@University of Nebraska - Lincoln. It has been accepted for inclusion in Publications from USDA-ARS / UNL Faculty by an authorized administrator of DigitalCommons@University of Nebraska - Lincoln. 
Authors

Ardell D. Halvorson, Alfred L. Black, Joseph M. Krupinsky, Steven D. Merrill, B. J. Wienhold, and Donald L. Tanaka 


\title{
Spring Wheat Response to Tillage System and Nitrogen Fertilization within a Crop-Fallow System
}

\author{
Ardell D. Halvorson,* Alfred L. Black, Joseph M. Krupinsky, Steven D. Merrill, \\ Brian J. Wienhold, and Donald L. Tanaka
}

\begin{abstract}
Spring wheat (Triticum aestivum L.) production in the northern Great Plains generally utilizes conventional tillage systems. A 12-yr study evaluated the effects of tillage system [conventional-till (CT), minimum-till (MT), and no-till (NT)], $N$ fertilizer rate $(0,22$, and 45 kg $\mathrm{N} \mathrm{ha}^{-1}$ ), and cultivar (Butte86 and Stoa) on spring wheat grain yields in a dryland spring wheat-fallow rotation (SW-F). Butte86 yields with $\mathrm{CT}$ exceeded $\mathrm{NT}$ yields in five out of 12 years with 0 and $22 \mathrm{~kg} \mathrm{~N} \mathrm{ha}^{-1}$ applied, and four years with $45 \mathrm{~kg} \mathrm{~N} \mathrm{ha}^{-1}$ applied. Stoa yields with $\mathrm{CT}$ exceeded NT yields in three out of 12 years with no $\mathrm{N}$ applied, four years with $22 \mathrm{~kg} \mathrm{~N} \mathrm{ha}^{-1}$ applied, and only one year with $45 \mathrm{~kg} \mathrm{~N} \mathrm{ha}^{-1}$ applied. Yields with NT exceeded those with CT in one year. Most years, yields with MT equaled those with CT. Responses to $\mathbf{N}$ tended to be greatest in years when spring soil $\mathrm{NO}_{3}-\mathrm{N}$ was lowest. Positive yield responses to $\mathbf{N}$ fertilization with $\mathbf{C T}$ occurred in three years with Butte86 and two years with Stoa; with MT, four years with Butte86 and two years with Stoa; and with NT, five years with Butte86 and three years with Stoa. Cultivars were not consistent in their response to tillage and $\mathbf{N}$ fertilization. These results indicate that farmers in the northern Great Plains can successfully produce spring wheat in a SW-F system using MT and NT systems, but yields may be slightly reduced when compared with CT systems some years.
\end{abstract}

$\mathrm{I}^{\mathrm{N}}$ N the semi-arid Great Plains, plant-available water (PAW) and soil erosion are major factors limiting agricultural production (Deibert et al., 1986; Stewart, 1990). Therefore, farmers need to manage crop residues and tillage to control soil erosion and effectively store and use the limited precipitation received for crop production (Black and Power, 1965; Merrill et al., 1995; Tanaka, 1985, 1989). The NT and MT systems are an effective step in efficiently saving more precipitation for crop production (Aase and Schaefer, 1996; Black and Bauer, 1990; Peterson et al., 1996; Tanaka, 1985; Tanaka and Anderson, 1997).

A.D. Halvorson, USDA-ARS, P.O. Box E, Fort Collins, CO 80522; A.L. Black, J.M. Krupinsky, S.D. Merrill, and D.L. Tanaka, USDAARS, P.O. Box 459, Mandan, ND; and B.J. Wienhold, USDA-ARS, 119 Keim Hall, East Campus, Univ. Nebraska, Lincoln, NE. Contribution from USDA-ARS. Received 3 June 1999. *Corresponding author (adhalvor@lamar.colostate.edu).

Published in Agron. J. 92:288-294 (2000).
Tanaka (1989) reported more soil water storage and surface residue cover with chemical fallow than with stubble mulch fallow in northeast Montana. The additional soil water, however, did not always result in increased spring wheat yields. Black and Power (1965) reported similar responses, but felt that the herbicides available at that time for use in chemical fallow may have reduced spring wheat yields in some years. Norwood et al. (1990) reported yearly variations in winter wheat-fallow yields between tillage systems in the central Great Plains due to climate variability.

The traditional crop-fallow system of farming using CT has used water (precipitation) inefficiently, as evidenced by the development of dryland saline-seeps in the northern Great Plains (Halvorson and Black, 1974). Use of MT and NT systems may enhance saline-seep development when using a crop-fallow system of farming (Halvorson, 1990). Deibert et al. (1986) suggested that farmers in the northern Great Plains need to reduce or eliminate the 20- to 21-mo fallow period from their production systems to attain more efficient use of limited water supplies. Improved levels of soil fertility have been shown to increase water-use efficiency of cropfallow systems by increasing crop yields (Black et al., 1981; Onken et al., 1990). Hall and Cholick (1989) reported varying responses of spring wheat cultivars to tillage system and a need to select cultivars for use under NT conditions. Because previous research tended to address either tillage system or fertility level alone, we conducted this study to determine the effects of tillage system, $\mathrm{N}$ fertilization rate, and cultivar on spring wheat grain yields in a dryland SW-F system.

\section{METHODS AND MATERIALS}

The study was initiated in 1984 on a Temvik-Wilton silt loam soil (fine-silty, mixed, superactive frigid Typic and Pachic Haplustolls) located near Mandan, ND. Surface soil $\mathrm{pH}$ was 6.4 , soil organic carbon was $21.4 \mathrm{~g} \mathrm{~kg}^{-1}$, and soil test $\mathrm{P}$ was 20 to $26 \mathrm{mg} \mathrm{kg}^{-1}$ in the spring of 1984 (Black and Tanaka,

Abbreviations: CT, conventional-till; MT, minimum-till; NT, no-till; PAW, plant-available water; TPAW, total plant-available water; SW-F, spring wheat-fallow rotation. 
Table 1. Number of tillage operations and burn-down herbicide applications made during the non-crop fallow period prior to each spring wheat crop for the conventional-till (CT), minimum-till (MT), and no-till (NT) treatments.

\begin{tabular}{|c|c|c|c|c|c|c|c|c|c|c|c|}
\hline \multirow[b]{3}{*}{ Year } & \multicolumn{5}{|c|}{ CT } & \multicolumn{4}{|c|}{ MT } & \multirow{2}{*}{\multicolumn{2}{|c|}{$\frac{\mathrm{NT}}{\text { Herbicide applications }}$}} \\
\hline & \multicolumn{3}{|c|}{ Tillage operations } & \multicolumn{2}{|c|}{ Herbicide applications } & \multicolumn{2}{|c|}{ Tillage operations } & \multicolumn{2}{|c|}{ Herbicide applications } & & \\
\hline & Disk & $\begin{array}{l}\text { Sweep } \\
\text { plow }\end{array}$ & Other & Glyphosate $\dagger$ & $\underset{\text { 2,4-D } \dagger}{\text { Glyphosate }}+$ & $\begin{array}{l}\text { Sweep } \\
\text { plow }\end{array}$ & Other & Glyphosate & $\underset{\text { 2,4-D }}{\text { Glyphosate }}+$ & Glyphosate & $\underset{\text { 2,4-D }}{\text { Glyphosate }}+$ \\
\hline 1985 & 1 & 3 & & & 1 & 2 & & & 2 & & 3 \\
\hline 1986 & 1 & 3 & & & 1 & 2 & & & 2 & & 3 \\
\hline 1987 & 1 & 3 & & & 1 & 1 & & & 3 & & 4 \\
\hline 1988 & 1 & 3 & & & 1 & 2 & & & 2 & & 3 \\
\hline 1989 & 2 & 1 & & 2 & & 2 & & 2 & & 3 & \\
\hline 1990 & 2 & 1 & & 2 & & 2 & & 3 & & 2 & 1 \\
\hline 1991 & 2 & & & & 2 & 2 & & & 3 & & 4 \\
\hline 1992 & & 2 & & 1 & & 1 & & 1 & 1 & 2 & 2 \\
\hline 1993 & $\mathbf{1}$ & 1 & & 3 & & 1 & & 4 & & 4 & \\
\hline 1994 & 2 & 1 & & & 1 & 1 & $\mathbf{M}$ & & 1 & & 2 \\
\hline 1995 & 1 & 3 & $\mathbf{H} \neq$ & & & 2 & M & 2 & & 3 & \\
\hline 1996 & 1 & 2 & M & & & 2 & & 1 & & 4 & \\
\hline
\end{tabular}

$\dagger$ Glyphosate = Isopropylamine salt of N-(phosphonomethyl)glycine; 2,4-D = 2,4-dichlorophenoxyacetic acid.

$\downarrow \mathbf{H}=$ Heavy duty long-tine harrow; $M=$ John Deere Mulch Master (John Deere, Moline, IL). Trade names and company names are included for the benefit of the reader and do not imply any endorsement or preferential treatment of the product by the USDA-ARS.

1997). Data collection was from 1985 through 1996. Spring wheat was produced in a crop-fallow system under three tillage systems, CT, MT, and NT. Nitrogen fertilizer was applied in early spring each crop year as a broadcast application of $\mathrm{NH}_{4} \mathrm{NO}_{3}$ at rates of 0,22 , and $45 \mathrm{~kg} \mathrm{~N}$ ha $^{-1}$. Exceptions were 1991 and 1992, when no $\mathrm{N}$ was applied because of a build-up of residual soil $\mathrm{NO}_{3}-\mathrm{N}$ due to drought conditions and low yields in 1988 and 1989. Phosphorus fertilizer was applied broadcast at a rate of $40 \mathrm{~kg} \mathrm{P} \mathrm{ha} \mathrm{h}^{-1}$ at the beginning of the study in October 1983. Soil test P levels in the 0- to $15-\mathrm{cm}$ depth averaged $16 \mathrm{mg} \mathrm{kg}^{-1}$ in 1991 and $13 \mathrm{mg} \mathrm{kg}^{-1}$ in 1996. Two spring wheat cultivars, Butte86 and Stoa, were used throughout the study. The cultivars had good yield potential but slightly different maturity dates. Each main block of the study was 137.2 by $73.1 \mathrm{~m}$ in size. Tillage plots $(45.7 \times 73.1$ $\mathrm{m})$ were oriented in a north-south direction, N plots $(137.2 \times$ $24.4 \mathrm{~m}$ ) in an east-west direction across all tillage plots, and cultivars $(22.9 \times 73.1 \mathrm{~m})$ in a north-south direction within tillage plots and across all $\mathrm{N}$ plots. The smallest plot, with the combination of all variables, was 22.9 by $24.4 \mathrm{~m}$. Duplicate sets of plots were established to allow all phases of the crop-fallow system to be present each year. Experimental design was a strip-strip-split plot with tillage and $\mathrm{N}$ rate treatments stripped and cultivar as subplots with 3 replications.

The fallow period began in August or September each year following spring wheat harvest and continued until spring wheat planting in May, 20- to 21-mo later. The CT treatments were generally not tilled in the fall following spring wheat harvest. Tillage operations (Table 1) for the fallow period generally began the following spring and summer, with one shallow $(<8 \mathrm{~cm})$ tillage operation with a sweep plow being performed just prior to spring wheat planting. Surface residue cover at planting was generally $<30 \%$. A burn-down herbicide was generally applied in mid- to late-July during the summer of fallow. Besides eliminating weeds, the operation also helped to maintain surface residue cover in the CT treatment by reducing the number of tillage operations. All tandem disk operations were performed at a depth of 8 to $12 \mathrm{~cm}$. The MT treatments were generally not tilled in the fall following spring wheat harvest, but were tilled once with a sweep plow the following spring. Burn-down herbicide was applied as needed throughout the fallow period. One sweep plow operation was performed just prior to spring wheat planting, with 30 to $60 \%$ residue cover at planting. All sweep plow operations were performed at a shallow depth $(<8 \mathrm{~cm})$. The NT treatments were not tilled, but received burn-down herbicide applications as needed to control weed growth during the fallow period (Table 1 ), with generally $>60 \%$ surface residue cover at planting. Residue cover estimates were visual observations based on experience with photographic measurements made of residue cover in these SW-F plots (Merrill et al., 1995). Spring-applied herbicides were used to control broadleaf and grassy weed species within the growing spring wheat crop. Weed control was uniform across all plots and excellent in most years.

The spring wheat was usually planted in early May at a seeding rate of about 3.2 million seeds ha $^{-1}$ using a NT disk drill with $17.8-\mathrm{cm}$ row spacing. For grain yield determination, the plots were harvested in mid- to late-August each year by hand cutting spring wheat samples from two $1.5 \mathrm{~m}^{2}$ areas within each plot (1985-1993). In 1994 through 1996, grain yields were determined from a $50 \mathrm{~m}^{2}$ area with a plot combine. Grain yields are expressed on a $120 \mathrm{~g} \mathrm{~kg}^{-1}$ water content basis.

Soil samples (one 3-cm diameter core per plot) were collected for gravimetric soil water and $\mathrm{NO}_{3}-\mathrm{N}$ analyses from one cultivar plot for each tillage and $\mathrm{N}$ fertilizer treatment. The samples were collected each spring (April) before $\mathrm{N}$ fertilization. Samples were collected in $30-\mathrm{cm}$ increments to a depth of $120 \mathrm{~cm}$. Soil $\mathrm{NO}_{3}-\mathrm{N}$ was determined by autoanalyzer (Lachat Instruments QuikChem Method 12-107-04-1-B, Lachat Instruments, Milwaukee, WI; Technicon Industrial Systems Industrial Method 100-70W, Technicon Industrial Systems, Tarrytown, NY) on a 5:1 extract/soil ratio. A $2 M \mathrm{KCL}$ extracting solution was used from 1985 through 1993 and a 0.01 $M \mathrm{CaSO}_{4}$ extracting solution was used from 1993 through 1996. Volumetric soil water content was estimated from gravimetric soil water measurements using a soil bulk density of $1.42 \mathrm{gm} \mathrm{cm}^{-3}$ for the profile (Black and Tanaka, 1997). Total plant-available water (TPAW) was estimated as the sum of spring soil PAW in the 0 - to $120-\mathrm{cm}$ profile plus growing season (April through August) precipitation. Spring soil PAW was estimated by subtracting the lowest measured soil water content $(152 \mathrm{~mm})$ in the 0 - to 120 -cm profile following spring wheat harvest during the 12-year study from soil water contents in the 0 - to $120-\mathrm{cm}$ soil profile each spring, similar to the lower limit method described by Ratliff et al. (1983) and Ritchie (1981). Precipitation was measured with a recording rain gauge at the site from April through October each year. November through March precipitation was estimated from the U.S. Weather Bureau measurements made at the Northern Great Plains Research Laboratory at Mandan, ND, located approximately $5 \mathrm{~km}$ northeast of the site.

Analysis of variance procedures were conducted using SAS 
statistical (ANOVA) procedures (SAS Institute, 1991) with years treated as a fixed variable. All differences discussed are significant at the $P=0.05$ probability level unless otherwise stated. An LSD was calculated only when the analysis of variance $F$-test was significant at the $P=0.05$ probability level.

\section{RESULTS AND DISCUSSION}

\section{Precipitation and Plant-Available Water}

Annual precipitation (Fig. 1) during the 12-yr period from 1985 through 1996 varied from a low of $206 \mathrm{~mm}$ in 1988 to a high of $655 \mathrm{~mm}$ in 1993 . The average annual precipitation during the study at the research site was $422 \mathrm{~mm}$, which was $13 \mathrm{~mm}$ more than the 82-year average at the Northern Great Plains Research Laboratory. Similar trends were observed for the April through August growing season precipitation, with a low of $132 \mathrm{~mm}$ in 1988 and a high of $602 \mathrm{~mm}$ in 1993, a site average of $296 \mathrm{~mm}$, and an 82-yr average of $287 \mathrm{~mm}$. Three consecutive years, 1988 to 1990, provided an opportunity to obtain information on the effects of drought on spring wheat production in a crop-fallow system. Total plant-available water was below $370 \mathrm{~mm}$ these three years (Fig. 1). Annual growing season precipitation in 1986, 1993, and 1995 was above average (Fig. 1). Total plant-available water also was considerably above the average (485 mm) during these years with TPAW levels of 603,841 , and $689 \mathrm{~mm}$ for 1986, 1993, and 1995, respectively. Tillage system had no effect on the level of spring PAW in this SW-F system, with PAW levels of 179, 180, and $184 \mathrm{~mm}$ for CT, MT, and NT treatments, respectively. Total plant-available water varied only with year (Fig. 1). The fact that no differences in PAW or TPAW were found among tillage treatments should probably be expected, since the 20 to 21 mo of fallow prior to planting the spring wheat crop allowed for recharge of the rootzone soil water most years. This observation is consistent with that of Pannkuk et al. (1997), who found that in the Pacific Northwest the fallow period tillage system had little effect on soil profile water at planting. In addition, soil water measurements were

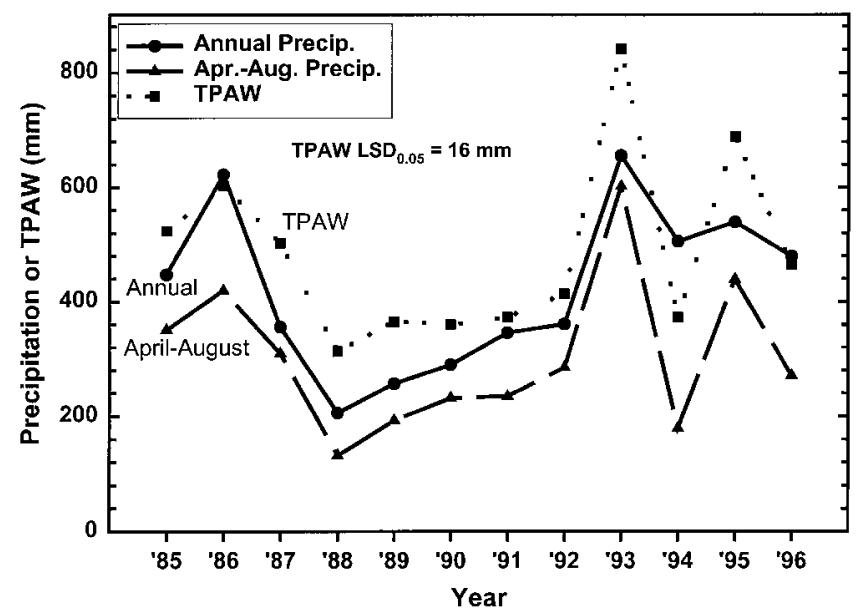

Fig. 1. Annual and growing season (April through August) precipitation and total plant-available water (TPAW) for each year at the study site.

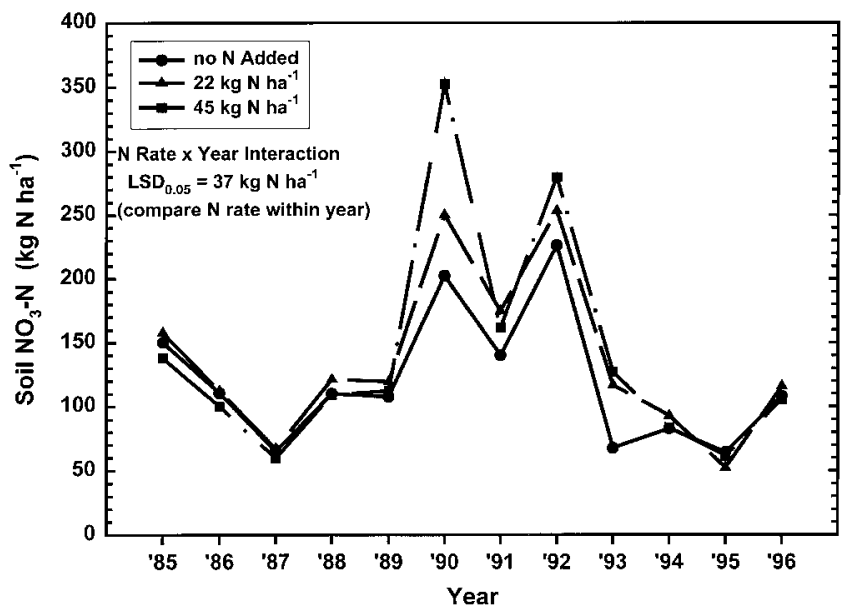

Fig. 2. Spring soil $\mathrm{NO}_{3}-\mathrm{N}$ in the $0-$ to $120-\mathrm{cm}$ soil profile as a function of years for $\mathbf{N}$ rate treatments.

made in early spring, immediately following spring thaw, and before any spring preplant tillage operations were performed to influence soil water loss. Cold soil temperatures also reduced evaporation loss from the soil surface.

\section{Soil $\mathrm{NO}_{3}-\mathbf{N}$}

Spring soil $\mathrm{NO}_{3}-\mathrm{N}$ levels varied with $\mathrm{N}$ rate $(P=$ $0.03)$ and year $(P=0.001)$ with a significant $\mathrm{N}$ rate $\times$ year $(P=0.0001)$ interaction. Spring soil $\mathrm{NO}_{3}-\mathrm{N}$ levels were similar for all $\mathrm{N}$ rates from 1985 through 1989 (Fig. 2). In 1990 and 1992, soil $\mathrm{NO}_{3}-\mathrm{N}$ levels increased, with the greatest level of spring soil $\mathrm{NO}_{3}-\mathrm{N}$ associated with the $45 \mathrm{~kg} \mathrm{ha}^{-1} \mathrm{~N}$ rate. Soil $\mathrm{NO}_{3}-\mathrm{N}$ levels declined in 1993, 1994, and 1995 for all $\mathrm{N}$ rates, with no difference in spring soil $\mathrm{NO}_{3}-\mathrm{N}$ among $\mathrm{N}$ rates in 1996. No $\mathrm{N}$ fertilization in 1991 and 1992 along with fair to good spring wheat yields probably contributed to this decline in spring soil $\mathrm{NO}_{3}-\mathrm{N}$ levels. All spring soil $\mathrm{NO}_{3}-\mathrm{N}$ levels had declined below 1985 levels by 1996. Average spring soil $\mathrm{NO}_{3}-\mathrm{N}$ (0- to $120-\mathrm{cm}$ depth) levels in the CT, MT, and NT plots were 144,136 , and $117 \mathrm{~kg} \mathrm{~N} \mathrm{ha}^{-1}$, respectively.

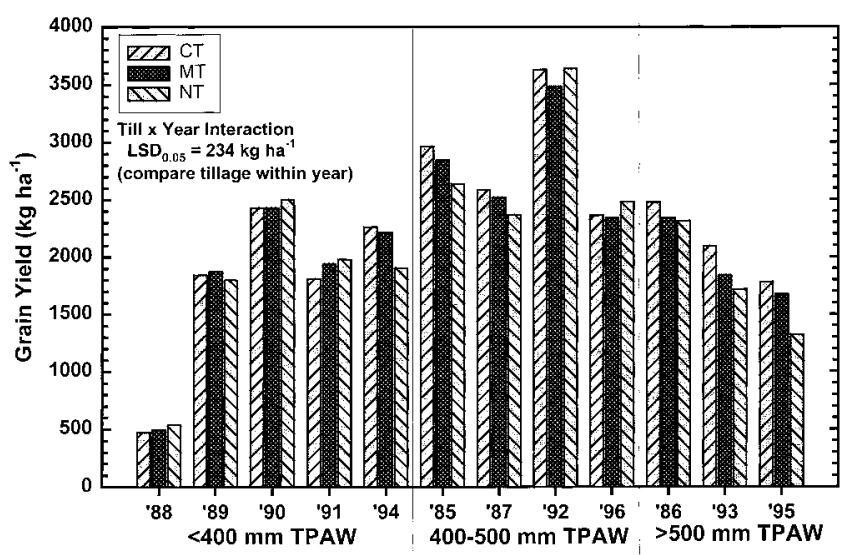

Fig. 3. Grain yield as a function of years, grouped by level of total plant-available water (TPAW), for conventional-till (CT), minimum-till (MT), and no-till (NT) treatments. 


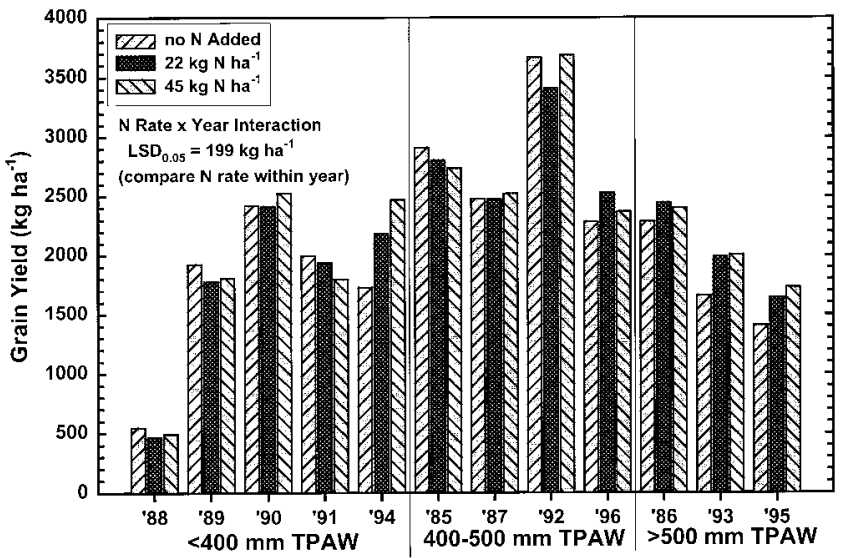

Fig. 4. Grain yield as a function of years, grouped by level of total plant-available water (TPAW), for $\mathrm{N}$ rate treatments.

\section{Grain Yields}

Spring wheat grain yields were significantly affected by tillage system $(P=0.0001), \mathrm{N}$ fertilization rate $(P=$ $0.01)$, and years $(P=0.0001)$. However, significant tillage $\times$ year $(P=0.028), \mathrm{N}$ rate $\times$ year $(P=0.0001)$, and tillage $\times \mathrm{N}$ rate $\times$ cultivar $\times$ year $(P=0.002)$ interactions for grain yield were present. The yearly yield data were grouped by level of TPAW $(<400 \mathrm{~mm}$, 400-500 mm, and $>500 \mathrm{~mm}$ ) in Fig. 3 and 4 to show the relationship of TPAW on spring wheat yields.

\section{Tillage $\times \mathbf{N}$ Rate $\times$ Cultivar $\times$ Year Interaction}

Grain yields for the tillage $\times N$ rate $\times$ cultivar $\times$ year interaction are shown in Table 2. Examination of the yield data in Table 2 reveals that there are no consistent trends in the yield data with regards to tillage, $\mathrm{N}$ rate, or cultivars over years. There were several factors that probably contributed to the four-way interaction. The presence of a high level of available soil $\mathrm{NO}_{3}-\mathrm{N}$ in all plots was sufficient to produce more grain yield than was attained in this study. Visually, vegetative growth appeared to be stimulated by $\mathrm{N}$ application most years, which tended to depress grain yields in drier years and increase grain yields in some of the wetter years. This observation is supported by harvest index and straw yield data not reported here. Excessive vegetative growth increased disease effects in some years, especially the wet years. Stoa heads and matures later than Butte86, which enhances its susceptibility to climate and disease interactions. The following discussion describes the spring wheat yield responses to the tillage, $\mathrm{N}$, and cultivar treatments within years.

\section{Tillage Effects on Yield}

By comparing tillage effects on spring wheat grain yields (Table 2 ) within $\mathrm{N}$ rate $\times$ cultivar $\times$ year, one finds that at the zero $\mathrm{N}$ rate, Butte86 yields with $\mathrm{CT}$ were greater than those with NT in 1985, 1986, 1987, 1993, and 1995. Stoa CT yields were greater than those with NT in 1985, 1993, and 1995. At the zero N rate, MT yields for Butte86 exceeded those with NT in 1985 and 1995; for Stoa, MT yields exceeded those with NT in 1993 and 1995. In 1992, Stoa yields with NT exceeded those with $\mathrm{CT}$ and $\mathrm{MT}$ at the zero $\mathrm{N}$ rate. With the application of $22 \mathrm{~kg} \mathrm{~N}^{-1}$, Butte86 yields with CT

Table 2. Spring wheat grain yields for the significant tillage $\times \mathbf{N}$ rate $\times$ cultivar $\times$ year interaction. $\dagger$

\begin{tabular}{|c|c|c|c|c|c|c|c|c|c|}
\hline \multirow[b]{3}{*}{ Year } & \multicolumn{9}{|c|}{ Nitrogen $(\mathbf{N})$ fertilization rate } \\
\hline & \multicolumn{3}{|c|}{0 kg N ha ${ }^{-1}$} & \multicolumn{3}{|c|}{22 kg N ha ${ }^{-1}$} & \multicolumn{3}{|c|}{$45 \mathrm{~kg} \mathrm{~N} \mathrm{ha}^{-1}$} \\
\hline & $\mathbf{C T} \nleftarrow$ & MT $\$$ & NT $\ddagger$ & CT & MT & NT & CT & MT & NT \\
\hline & \multicolumn{9}{|c|}{ Butte 86} \\
\hline 1985 & 3055 & 3033 & 2581 & 3062 & 2789 & 2482 & 2784 & 2813 & 2615 \\
\hline 1986 & 2772 & 2090 & 2344 & 2548 & 2419 & 2512 & 2694 & 2383 & 2390 \\
\hline 1987 & 2560 & 2434 & 2273 & 2734 & 2378 & 2448 & 2578 & 2528 & 2341 \\
\hline 1988 & 522 & 507 & 542 & 333 & 411 & 521 & 425 & 366 & 515 \\
\hline 1989 & 1904 & 1997 & 1727 & 1872 & 1684 & 1736 & 1895 & 1937 & 1769 \\
\hline 1990 & 2259 & 2424 & 2307 & 2398 & 2254 & 2471 & 2439 & 2577 & 2595 \\
\hline 1991 & 1910 & 2070 & 2027 & 1875 & 1990 & 1963 & 1657 & 1990 & 1881 \\
\hline 1992 & 3746 & 3518 & 3830 & 3494 & 3626 & 3366 & 4180 & 3585 & 3877 \\
\hline 1993 & 2370 & 1546 & 1343 & 2417 & 2019 & 1849 & 2211 & 2020 & 2007 \\
\hline 1994 & 1889 & 1702 & 1648 & 2438 & 2332 & 1850 & 2617 & 2531 & 2334 \\
\hline 1995 & 1900 & 1916 & 769 & 2143 & 1888 & 1500 & 2182 & 1647 & 1695 \\
\hline \multirow[t]{2}{*}{1996} & 2476 & 2255 & 2243 & 2724 & 2675 & 2637 & 2244 & 2579 & 2735 \\
\hline & \multicolumn{9}{|c|}{ Stoa } \\
\hline 1985 & 3108 & 2966 & 2725 & 2900 & 2902 & 2684 & 2887 & 2569 & 2750 \\
\hline 1986 & 2264 & 2218 & 2039 & 2413 & 2326 & 2460 & 2166 & 2612 & 2149 \\
\hline 1987 & 2569 & 2645 & 2392 & 2552 & 2415 & 2322 & 2532 & 2727 & 2436 \\
\hline 1988 & 539 & 573 & 606 & 485 & 541 & 506 & 523 & 570 & 542 \\
\hline 1989 & 1944 & 2038 & 1949 & 1718 & 1802 & 1862 & 1725 & 1772 & 1738 \\
\hline 1990 & 2527 & 2349 & 2653 & 2309 & 2664 & 2403 & 2647 & 2312 & 2588 \\
\hline 1991 & 1878 & 2016 & 2082 & 1910 & 1829 & 2065 & 1632 & 1751 & 1864 \\
\hline 1992 & 3394 & 3532 & 3976 & 3569 & 3110 & 3279 & 3405 & 3541 & 3523 \\
\hline 1993 & 1521 & 1727 & 1452 & 2112 & 1814 & 1716 & 1942 & 1920 & 1937 \\
\hline 1994 & 1701 & 1850 & 1587 & 2388 & 2349 & 1740 & 2543 & 2518 & 2275 \\
\hline 1995 & 1444 & 1417 & 1003 & 1428 & 1526 & 1359 & 1598 & 1654 & 1600 \\
\hline 1996 & 2245 & 2121 & 2379 & 2333 & 2364 & 2439 & 2161 & 2054 & 2449 \\
\hline
\end{tabular}

$\dagger$ Interaction $\mathbf{L S D}_{0.05}=\mathbf{2 7 2} \mathbf{k g ~ h a}^{-1}\left(\right.$ compare tillage within $\mathrm{N}$ rate $\times$ cultivar $\times$ year); Interaction $\mathrm{LSD}_{0.05}=\mathbf{2 7 4} \mathbf{k g ~ h a}^{-1}($ compare $\mathrm{N}$ rates within tillage $\times$ cultivar $\times$ year).

$\$ \mathbf{C T}=$ conventional-till; $\mathbf{M T}=$ minimum-till; and $\mathbf{N T}=$ no till. 
exceeded those with NT in 1985, 1987, 1993, 1994, and 1995. Butte86 yields with MT exceeded those with NT in 1985, 1994, and 1995. Butte86 yields with CT exceeded those with MT in 1985, 1987, and 1993. With the application of $22 \mathrm{~kg} \mathrm{~N} \mathrm{ha}^{-1}$, Stoa yields with CT exceeded those with NT in 1985, 1992, 1993, and 1994. Stoa yields with MT exceeded those of NT in 1985 and 1994. Stoa yields with CT exceeded those with MT in 1992 and 1993. With the application of $45 \mathrm{~kg} \mathrm{~N} \mathrm{ha}^{-1}$, Butte86 yields with CT exceeded those with NT in 1986, 1992, 1994, and 1995. In 1996, Butte86 yields with NT and MT exceeded those with CT at the $45 \mathrm{~kg} \mathrm{ha}^{-1} \mathrm{~N}$ rate. Butte86 yields with MT exceeded those with CT in 1991 and 1996 and those with NT in 1994 and 1996. Stoa yields with CT at the $45 \mathrm{~kg} \mathrm{ha}^{-1} \mathrm{~N}$ rate exceeded those with NT in 1987, and NT yields exceeded those of CT and MT in 1996. Stoa yields with MT exceeded those with CT in 1986 and those with NT in 1986 and 1987.

\section{Nitrogen Effects on Yield}

Comparing $\mathrm{N}$ effects on spring wheat grain yield (Table 2) within tillage $\times$ cultivar $\times$ year, one finds that with CT, Butte86 yields were increased in 1992, 1994 , and 1995 and decreased in 1985 and 1996 with the application of $45 \mathrm{~kg} \mathrm{~N} \mathrm{ha}^{-1}$ when compared with yields with no $\mathrm{N}$ applied. Application of $22 \mathrm{~kg} \mathrm{~N}^{-1}$ increased Butte86 yields with CT in 1994 and 1995 above those with no N applied. With CT, Stoa yields were increased with application of 22 and $45 \mathrm{~kg} \mathrm{~N}^{-1}$ when compared with yields with no N applied in 1993 and 1994. Application of $45 \mathrm{~kg} \mathrm{~N} \mathrm{ha}^{-1}$ decreased Stoa yields with CT in 1991 when compared with the $22 \mathrm{~kg} \mathrm{~N}^{-1}$ rate. With MT, N fertilization increased Butte86 yields in 1986, 1993, 1994, and 1996 above those yields with no $\mathrm{N}$ applied. Application of $45 \mathrm{~kg} \mathrm{~N}^{-1}$ did not result in greater yields in these years than with $22 \mathrm{~kg} \mathrm{~N}^{-1}$ applied. Stoa yields with MT were decreased in 1985 and increased in 1986 and 1994 by the application of 45 $\mathrm{kg} \mathrm{N} \mathrm{ha}^{-1}$ when compared with yields with no $\mathrm{N}$ applied. Application of $22 \mathrm{~kg} \mathrm{~N} \mathrm{ha}^{-1}$ increased Stoa yields with MT above those with no N applied in 1990 and 1994. With NT, application of $45 \mathrm{~kg} \mathrm{~N} \mathrm{ha}^{-1}$ increased Butte 86 yields in 1990, 1993, 1994, 1995, and 1996 when compared with yields with no N applied. Application of 22 $\mathrm{kg} \mathrm{N}^{-1}$ increased Butte86 yields with NT in 1993, 1995, and 1996 when compared with yields with no N applied. Stoa yields with NT were increased with application of $45 \mathrm{~kg} \mathrm{~N}^{-1}$ in 1993, 1994, and 1995 when compared with yields with no $\mathrm{N}$ applied, but decreased yields in 1992 when residual soil $\mathrm{NO}_{3}-\mathrm{N}$ levels were high. Stoa yields with application of $22 \mathrm{~kg} \mathrm{~N} \mathrm{ha}^{-1}$ with NT were only increased in 1986 and 1995 when compared with yields with no $\mathrm{N}$ applied.

\section{Cultivar and Year Effects on Yield}

Cultivar response to tillage and $\mathrm{N}$ varied from year to year, with Butte86 tending to have slightly greater yields than Stoa in most years. Butte86 responded more frequently to $\mathrm{N}$ application than did Stoa in this SW-F system. Grain yields were severely depressed in 1988 compared with other years due to very low amounts of growing season precipitation (Fig. 1). Grain yields in 1989 were not depressed as much in this SW-F system as they were in the adjacent annual cropping system (Halvorson et al., 1999a, 1999b, and 2000), which did not have an extended fallow period between crops. The till $\times \mathrm{N}$ rate $\times$ cultivar $\times$ year interaction resulted because of the variation in spring wheat response to treatment from year to year. An extended fallow period prior to crop planting tends to mask yearly treatment responses to tillage, $\mathbf{N}$ fertilization, or cultivar, similar to observations made by Pannkuk et al. (1997) in the Pacific Northwest.

\section{Tillage $\times$ Year Interaction}

The grain yield tillage $\times$ year interaction is shown in Fig. 3. During the five years with $<400 \mathrm{~mm}$ of TPAW, tillage system did not significantly affect grain yields, except for 1994 when yields were CT $=$ MT $>$ NT. Grain yields were lowest for 1988, when precipitation and TPAW (Fig. 1) were low. In 1989 and 1990, grain yields in this SW-F system were not affected as much by the drought conditions as the grain yields in the annual cropping system (Halvorson et al. 1999a, 1999b, 2000). During the years with 400 to $500 \mathrm{~mm}$ TPAW, yield responses to tillage system were only significant in 1985, when grain yields with CT were greater than those with NT. During years of $>500 \mathrm{~mm}$ TPAW, tillage system affected grain yields in $1993(\mathrm{CT}>\mathrm{MT}=\mathrm{NT})$ and $1995(\mathrm{CT}=\mathrm{MT}>\mathrm{NT})$. Grain yields in the $>500$ $\mathrm{mm}$ TPAW group did not increase above those within the 400 to $500 \mathrm{~mm}$ TPAW group, as one may expect. This indicates that water was not the limiting factor in the $>500 \mathrm{~mm}$ TPAW group. One reason for grain yields not increasing above those within the 400 to $500 \mathrm{~mm}$ TPAW group would be an increase in leaf spot disease severity associated with higher moisture levels (Krupinsky et al., 1997, 1998).

\section{N Rate $\times$ Year Interaction}

The $\mathrm{N}$ rate $\times$ year interaction effects on grain yield are shown in Fig. 4. During the years of $<400 \mathrm{~mm}$ TPAW, a negative response to $\mathrm{N}$ application was observed in 1991, with similar trends in 1988 and 1989. This negative yield response to $\mathrm{N}$ fertilization probably resulted because of the increased early vegetative growth observed with $\mathrm{N}$ application, which increased the transpirational demand, resulting in increased plant water stress during grain fill. Nielsen and Halvorson (1991) reported similar effects of $\mathrm{N}$ fertilization on winter wheat during years with limited TPAW. A positive response to $\mathrm{N}$ application was observed in 1994, when residual spring soil $\mathrm{NO}_{3}-\mathrm{N}$ was lower at planting than in previous years. Grain yield responses to $\mathrm{N}$ fertilization during years with 400 to $500 \mathrm{~mm}$ of TPAW varied from year to year. In 1992, grain yields were less with $22 \mathrm{~kg}$ $\mathrm{N}$ ha $^{-1}$ than for the other $\mathrm{N}$ treatments. In 1996, grain yields were increased with the application of $22 \mathrm{~kg} \mathrm{~N}$ $\mathrm{ha}^{-1}$. During the years with $>500 \mathrm{~mm}$ TPAW, grain 
yields were optimized with $22 \mathrm{~kg} \mathrm{~N}^{-1}$ in 1993 and 1995. The lack of a consistent $\mathrm{N}$ response suggests that the soil was able to mineralize sufficient $\mathrm{N}$ during the 20- to 21-mo fallow period to meet spring wheat needs the following year. Response to $\mathrm{N}$ fertilization was greatest in 1993, 1994, and 1995 when spring residual $\mathrm{N}$ levels were $<100 \mathrm{~kg} \mathrm{ha}^{-1}$.

When evaluating spring wheat plants for leaf spot diseases during another phase of this study, differences among $\mathrm{N}$ treatments (both cultivars) were significant for $10 \%$ of the disease ratings, compared with $45 \%$ of the ratings for spring wheat in the continuous cropping system (Halvorson et al., 2000). One can speculate that applied $\mathrm{N}$ had a lesser impact in the SW-F system because of the higher level of available soil N. This higher level resulted from $\mathrm{N}$ being mineralized from soil organic matter during the 20- to 21-mo fallow period. When differences were significant, higher levels of disease severity were associated with the zero $\mathrm{N}$ fertilizer treatment compared with the higher $\mathrm{N}$ treatments. The $\mathrm{N} \times$ tillage interaction was significant for $21 \%$ of the ratings for disease severity. With no $\mathrm{N}$ added, leaf spot severity (data not reported) was higher with NT than with $\mathrm{CT}$, but at higher $\mathrm{N}$ levels, the difference in leaf spot severity for the tillage treatments was greatly reduced or eliminated (Krupinsky et al., 1997, 1998). Nitrogen fertilization played an important role in maintaining a healthy spring wheat plant under NT conditions.

\section{Main Effects}

Grain yields by tillage systems were in the order of CT $>$ MT > NT with respective yields of 2227, 2167, and $2101 \mathrm{~kg} \mathrm{ha}^{-1}$. Average grain yields were 2110, 2173, and $2212 \mathrm{~kg} \mathrm{ha}^{-1}$ for the 0,22 , and $45 \mathrm{~kg} \mathrm{~N}^{-1}$ treatments, respectively. Average 12-yr grain yields for Butte86 (2203 kg ha $\left.{ }^{-1}\right)$ were not different from those of Stoa $\left(2126 \mathrm{~kg} \mathrm{ha}^{-1}\right)$.

\section{SUMMARY}

The results of this study show that grain yields in this SW-F system were generally not enhanced using MT and NT systems when compared with CT. Butte 86 yields with CT exceeded those with NT in five out of 12 years with the application of 0 and $22 \mathrm{~kg} \mathrm{~N} \mathrm{ha}^{-1}$ and in four out of 12 years with the application of $45 \mathrm{~kg} \mathrm{~N} \mathrm{ha}^{-1}$. Stoa yields with CT exceeded those with NT in three out of 12 years without $\mathrm{N}$ fertilization, four out of 12 years with $22 \mathrm{~kg} \mathrm{~N} \mathrm{ha}^{-1}$ applied, and one out of 12 years with $45 \mathrm{~kg} \mathrm{~N} \mathrm{ha}^{-1}$ applied. Stoa yields with NT exceeded those with CT in one year at the 0 and $45 \mathrm{~kg} \mathrm{ha}^{-1} \mathrm{~N}$ rates, and Butte 86 yields in one year with $45 \mathrm{~kg} \mathrm{~N} \mathrm{ha}^{-1}$. Yields of both cultivars with MT exceeded those with NT in two out of 12 years at the 0 and $45 \mathrm{~kg} \mathrm{ha}^{-1} \mathrm{~N}$ rates. Butte 86 yields with $22 \mathrm{~kg} \mathrm{~N}^{-1}$ applied with MT exceeded those with NT in three out of 12 years, and Stoa yields in two out of 12 years. Except for one or two years, MT yields equaled those with CT when N fertilizer was applied.

Spring wheat response to $\mathrm{N}$ fertilization was not consistent from year to year, but yield response to $\mathrm{N}$ fertil- ization tended to be greatest in years when spring soil $\mathrm{NO}_{3}-\mathrm{N}$ was lowest and precipitation was high. Nitrogen fertilization did help reduce the leaf disease pressure (Krupinsky et al., 1997,1998) in years when leaf diseases were a problem. Butte 86 yields with $\mathrm{CT}$ were increased by the application of $22 \mathrm{~kg} \mathrm{~N} \mathrm{ha}^{-1}$ in two years and by the application of $45 \mathrm{~kg} \mathrm{~N} \mathrm{ha}^{-1}$ in three years, and decreased by the application of $45 \mathrm{~kg} \mathrm{~N} \mathrm{ha}^{-1}$ in two years. Stoa yields with $\mathrm{CT}$ were increased by $\mathrm{N}$ application in two out of 12 years and decreased in one year with the application of $45 \mathrm{~kg} \mathrm{~N} \mathrm{ha}^{-1}$. Butte86 yields with MT were increased in four out of 12 years with the application of $\mathrm{N}$, and Stoa yields in two out of 12 years. Butte 86 yields with NT were increased above those with no $\mathrm{N}$ applied in five out of 12 years with the application of $45 \mathrm{~kg} \mathrm{~N} \mathrm{ha}^{-1}$ and in three out of 12 years with the application of $22 \mathrm{~kg} \mathrm{~N} \mathrm{ha}^{-1}$. Stoa yields with NT were increased above those with no $\mathrm{N}$ applied in two out of 12 years with the application of $22 \mathrm{~kg} \mathrm{~N} \mathrm{ha}^{-1}$, in three out of 12 years with $45 \mathrm{~kg} \mathrm{~N}^{-1}$ applied, and decreased in one year with the application of $45 \mathrm{~kg} \mathrm{~N} \mathrm{ha}^{-1}$.

These variations in yearly yield response to tillage and $\mathrm{N}$ treatments are in agreement with those observed by Tanaka (1989) in northeast Montana, Norwood et al. (1990) in western Kansas, and Pannkuk et al. (1997) in the Pacific Northwest for wheat-fallow systems. Spring soil water levels were similar for all tillage treatments at spring wheat planting each year. Spring wheat yields were abnormally low in only one year, 1988, which had the lowest level of precipitation and TPAW. Grain yields were maintained near normal in 1989 and 1990, despite the low level of growing season precipitation, in contrast to low spring wheat yields in the adjacent annual cropping system (Halvorson et al., 2000). This demonstrates the benefit of a fallow period preceding a crop during drought years. Spring soil $\mathrm{NO}_{3}-\mathrm{N}$ levels increased following the drought years, possibly due to reduced crop N use in 1988 and 1989, but returned to 1985 levels by 1996 for all N rates. Spring soil N levels were greater than $100 \mathrm{~kg} \mathrm{~N} \mathrm{ha}^{-1}$ in eight out of the 12 years for the zero $\mathrm{N}$ fertilizer rate. This was nearly adequate for the spring wheat yield levels attained in this study. These results indicate that farmers in the northern Great Plains can successfully produce spring wheat in a SW-F system using MT and NT systems, but yields may be slightly reduced in some years when compared with CT systems. Producers need to consider changing to more intensive cropping systems to reap the benefits of the MT and NT systems compared with $\mathrm{CT}$ in the northern Great Plains.

\section{ACKNOWLEDGMENTS}

The authors acknowledge the contribution of the Area IV Soil Conservation Districts in North Dakota for providing the land and assisting with financial resources to conduct this longterm study; the assistance of Dr. Gary Richardson, USDAARS Statistician, Fort Collins, CO, with the statistical analyses; and the assistance of F. Jacober, J. Harms, L. Renner, M. Hatzenbuhler, and G. Brucker in conducting the study and collecting the field and laboratory data. 


\section{REFERENCES}

Aase, J.K., and G.M. Schaefer. 1996. Economics of tillage practices and spring wheat and barley crop sequence in the northern Great Plains. J. Soil Water Conserv. 51(2):167-170.

Black, A.L., and A. Bauer. 1990. Strategies for storing and conserving soil water in the northern Great Plains. p. 137-139. In P.W. Unger, W.R. Jordan, T.V.Sneed, and R.W. Jensen (ed.) Proc. International Conference on Dryland Farming, Bushland, Texas. 15-19 Aug. 1988. Texas Agric. Exp. Sta., College Station.

Black, A.L., and J.F. Power. 1965. Effect of chemical and mechanical fallow methods on moisture storage, wheat yields, and soil erodibility. Soil Sci. Soc. Am. Proc. 29:465-468.

Black, A.L., and D.L. Tanaka. 1997. A conservation tillage-cropping systems study in the northern Great Plains of the United States. p. 335-342. In E.A. Paul, K. Paustian, E.T. Elliott, and C.V. Cole (ed.) Soil organic matter in temperate agroecosystems-long-term experiments in North America. CRC Press. Boca Raton, FL.

Black, A.L., P.L. Brown, A.D. Halvorson, and F.H. Siddoway. 1981. Dryland cropping strategies for efficient water-use to control saline seeps in the northern Great Plains, USA. Agric. Water Manage. 4:295-311.

Deibert, E.J., E. French, and B. Hoag. 1986. Water storage and use by spring wheat under conventional tillage and no-till in continuous and alternate crop-fallow systems in the northern Great Plains. J. Soil Water Conserv. 41:53-58.

Hall, E.F., and F.A. Cholick. 1989. Cultivar $\times$ tillage interaction of hard red spring wheat cultivars. Agron. J. 81:789-792.

Halvorson, A.D. 1990. Management of dryland saline seeps. p. 372392. In K.K. Tanji (ed.) Agricultural salinity assessment and management. ASCE Manuals and Reports on Engineering Practice 71 Am. Soc. Civil Eng., New York.

Halvorson, A.D., and A.L. Black. 1974. Saline-seep development in dryland soils of northeastern Montana. J. Soil Water Conserv. 29(2):77-81.

Halvorson, A.D., A.L. Black, J.M. Krupinsky, and S.D. Merrill. 1999a. Dryland winter wheat response to tillage and $\mathrm{N}$ within an annual cropping system. Agron. J. 91:702-707.

Halvorson, A.D., A.L. Black, J.M. Krupinsky, S.D. Merrill, and D.L. Tanaka. 1999b. Sunflower response to tillage and $\mathrm{N}$ under intensive cropping in wheat rotation. Agron. J. 91:637-642.

Halvorson, A.D., A.L. Black, J.M. Krupinsky, S.D. Merrill, B.J. Wienhold, and D.L. Tanaka. 2000. Spring wheat response to tillage and nitrogen fertilization in rotation with sunflower and winter wheat. Agron. J. 92:136-144.

Krupinsky, J.M., A.D. Halvorson, and A.L. Black. 1997. Diseases in zero-till cereal crops. p. 93-102. In Proc. Nineteenth Annual Manitoba-North Dakota Zero Tillage Workshop. 27-29 Jan. 1997.
Manitoba-North Dakota Zero Tillage Farmers' Association, Brandon, Manitoba, Canada.

Krupinsky, J.M., A.D. Halvorson, and A.L. Black. 1998. Leaf spot diseases of wheat in a conservation tillage study. p. 322-326. In E. Duveiller, H.J. Dubin, J. Reeves, and A. McNab (ed.) Helminthosporium blights of wheat: Spot blotch and tan spot. CIYMMT, Mexico, DF.

Merrill, S.D., A.L. Black, and T.M. Zobeck. 1995. Overwinter changes in dry aggregate size distribution influencing wind erodibility in a spring wheat-summerfallow cropping system. J. Minn. Acad. Sci. 59(2):27-36.

Nielsen, D.C., and A.D. Halvorson. 1991. Nitrogen fertility influence on water stress and yield of winter wheat. Agron. J. 83:1065-1070.

Norwood, C.A., A.J. Schlegel, D.W. Morishita, and R.E. Gwin. 1990 Reduced tillage cropping systems in southwest Kansas. p. 830-832. In P.W. Unger, W.R. Jordan, T.V. Sneed, and R.W. Jensen (ed.) Proc. International Conference on Dryland Farming, Bushland, Texas. 15-19 Aug. 1988. Texas Agric. Exp. Sta., College Station.

Onken, A.B., C.W. Wendt, and A.D. Halvorson. 1990. Soil fertility and water use efficiency. p. 441-444. In P.W. Unger, W.R. Jordan, T.V. Sneed, and R.W. Jensen (ed.), Proc. International Conference on Dryland Farming, Bushland, Texas. 15-19 Aug. 1988. Texas Agric. Exp. Sta., College Station.

Pannkuk, C.D., R.I. Papendick, and K.E. Saxton. 1997. Fallow management effects on soil water storage and wheat yields in the Pacific Northwest. Agron. J. 89:386-391.

Peterson, G.A., A.J. Schlegel, D.L. Tanaka, and O.R. Jones. 1996 Precipitation use efficiency as affected by cropping and tillage systems. J. Prod. Agric. 9:180-186.

Ratliff, L.F., J.T. Ritchie, and D.K. Cassel. 1983. A survey of fieldmeasured limits of soil water availability and related laboratorymeasured properties. Soil Sci. Soc. Am. J. 47:770-775.

Ritchie, J.T. 1981. Soil water availability. Plant Soil 58:327-338.

SAS Institute Inc. 1991. SAS/STAT Users Guide, Version 6, 4th Edition. SAS Institute, Cary, NC.

Stewart, B.A. 1990. Dryland farming: The North American experience. p. 54-59. In P.W. Unger, W.R. Jordan, T.V. Sneed, and R.W. Jensen (eds), Proc. International Conference on Dryland Farming, Bushland, Texas. 15-19 Aug. 1988. Texas Agric. Exp. Sta., College Station.

Tanaka, D.L. 1985. Chemical and stubble-mulch fallow influences on seasonal soil water contents. Soil Sci. Soc. Am. J. 49:728-733.

Tanaka, D.L. 1989. Spring wheat plant parameters as affected by fallow methods in the northern Great Plains. Soil Sci. Soc. Am. J. 53:1506-1511.

Tanaka, D.L., and R.L. Anderson. 1997. Soil water storage and precipitation storage efficiency of conservation tillage systems. J. Soil Water Conserv. 52(5):363-367. 